\title{
Expression of language and culture commonality in world language corporations
}

\author{
Nigmatova Lolahon Khamidovna \\ Associate professor of \\ Bukhara State University \\ nigmatovalolaxon@gmail.com
}

\begin{abstract}
because language is a reflection of reality, and culture is an integral part of that reality, language is a simple reflection of culture. Thus, while the impact of culture on language is clear, the question of the impact of language on culture remains open for now.

Key words: culture, impact of language, methodological approaches, philosophical linguists, linguistic picture of the world.

\section{I.Introduction}

Today, the issue of the interdependence of culture and language is very complex and multifaceted, manifested in a number of methodological approaches. The first approach developed by philosophers such as S.A. Atanovsky, G.A. Brutian, E.I. Kukushkina, E.S. Markaryan substantiates the interdependence of language and culture with one-way movement.

Nineteenth-century philosophical linguists V.Humboldt, A.A.Potebnya and others interpret language as an expression of spiritual power, psyche. Language is such an environment that we cannot live in a society without its participation. According to Humboldt, language is "a world that exists between the inner world of man and the outer reality." Because language is the "environment" that surrounds us, it cannot exist as an objective reality outside of us: language is in us, in our minds, in our memory. It changes its image with every movement of thinking, with every new socio-cultural situation.

\section{II.Literature review}

E.Sepir, B.Worf schools propose a second approach: the problem has been studied by different schools of the new Humboldtists, who have developed a relative hypothesis of language. According to them, people see the world through the prism of their mother tongue, that is, in different ways. Proponents of the idea argue that "the real world exists as it is expressed in language." If each language reflects the truth in its own way, then the languages differ in the "linguistic picture of the world". "Language acts as a creative force in all spheres of spiritual life."
\end{abstract}

\section{III.Analysis}

There is also a next-third view of the interdependence between language and culture. This approach sees language as evidence of culture because:

1) it is an integral part of the culture inherited from our ancestors;

2) language - the main means of teaching culture;

3) language is the most important of all cultural phenomena. Because if we want to understand the essence of culture - science, religion, literature, then we need to look at these phenomena as codes formed like language. So far, natural language has the best developed model.

Therefore, a conceptual understanding of culture can only be realized through natural language. Professor N.F. Alefirenko's approach to the problem of the relationship between language and culture is also noteworthy. 
According to N.F. Alefirenko, this relationship can be considered only if the lost (central) element in the chain - consciousness - is restored. The fact is that the main component of culture is the collection, processing (modification) of information obtained in the process of human activity is a function of public consciousness. As a result of labor activity, he creates an image of ordinary consciousness; the secondary change of mental content serves as a source of perception of the creative, imaginary world that develops the primary forms of world development.

Normal mental images are formed by verbal and nonverbal means. The creative transformation of experimental information is accomplished primarily through lingvocreative thinking. Therefore, in order to deepen our understanding of the relationship between language and culture, it is expedient to distinguish between the concepts of "cognitive consciousness" and "linguistic consciousness" (Y.N. Karaulov). If the former, as a rule, includes the results of cognition, the latter, in addition to thinking, includes other forms of reflection of the world around it - emotional, aesthetic, expressive-evaluative, and so on.

Thus, language and culture are connected to each other through a large number of threads, so there are different approaches to the question of the interaction of these concepts. According to V.G. Korolenko, the word is "a dead tool and not an external mirror of literature; it is, at the same time, a living, moving, evolving spirit, a means of perfection." Language is a mechanism for coding and reflecting culture.

A.N. Belyaev in his article "On the interaction of language and culture" explains the relationship between language and culture.

The author discusses the relationship between language, thinking, and culture. V.von Humboldt tries to comment on the basis of his thoughts: "In linguistics, there has always been a tendency to study language in close connection with culture. V.von Humboldt emphasizes that there is a direct and indirect connection between language, thought and culture. As he himself pointed out, the main thing in the human mind is the external world, events, the inner world of man, the naturalness of the human spirit, a set of objective and subjective phenomena.

There are several bases for understanding a sign today: a sign belonging to the world of communication (1); a sign that is equal to every member of society, both externally and internally, in relation to any member of society (2); sign material or material perceived by the senses in any case (3); motionless character (4). A.N. Belyaev emphasizes the importance of understanding the sign and distinguishes points of convergence and two additional characteristics:

a) personality and integrity, in which the irrational systemic character is always present, with the fair functions of the whole function, in addition to the other set of characters;

b) the character's belonging to the world of culture.

The conclusion that there is interdependence between language and culture is the result of Humboldt's reference to concepts such as nation, the spirit of the nation, understanding through language, and worldview, which are considered modern humanities. Analyzing the interaction of language and culture in human history, V.Humboldt wrote: "Language is closely connected with the spiritual development of mankind; it reflects every stage of his inner spiritual development or regression."

Humboldt's most effective ideas are further developed, first of all, in linguistic researches in the field of cognitology, ethnolinguistics, pragmalinguistics.

Based on the above, the following conclusions can be drawn about the relationship between language, thinking and culture:

1. The interdependence of culture and language is a cognitive-pragmatic phenomenon. Language as a means of expressing culture develops in it, expresses it. Therefore, language can be considered as an integral part of culture, its means, the reality of our psyche, the face of culture.

2. Language reveals the peculiarities of the national mentality. It is at the same time a product of culture and an important component of it, a condition of the existence of culture. Moreover, language is 
a specific way of cultural existence, a factor in the formation of cultural codes.

3. Culture lives and develops in the "shell of language", but many perceive language as something that is not naturally an ecological object. In fact, language is not only a means of communication, but also an invaluable historical monument and a treasure of folk culture.

4. Culture, including speech, protects the civilized core of all nations, taking into account the spiritual and moral values of humanity.

\section{IV.Discussion}

Linguoculturology is the study of linguistics, which reflects the features of language, culture, the manifestation of folk culture in the language. Linguocultural analysis of language units describes the peculiarities of linguistics and cultural community, national-cultural characteristics, explains the importance of the concept of communicative category, national culture.

The main task of linguoculturology is to describe the cultural origins of the communication space of a particular linguoculturological circle, discourse and language, as well as the interpretation of the terms of cultural symbols of the linguistic unit, from the perspective of historical memory of the people. The interaction of language and culture is manifested in a complex unit of linguistic, cultural and linguocultural composition consisting of linguistic and culturological components.

The basis of the possession of a linguoculturological sign is the process of expressing cultural and linguistic identity, which is the result of the reflection of at least one of the components of culture through a linguistic form, a medium. Thus, linguoculturological research will focus on the content of culture (cultural essence, cultural sphere, values), the nature and form of culture (symbol, cultural code, archetypes), culture and the people who carry it (identity language or identity). Typically, the study of the reflection of a cultural component through language units is associated with lexical system units as the primary means of nomination.

When researchers compare the lexical-semantic systems of different languages, they highlight the linguistic specificity inherent in a particular language. Such a comparison can be made with a cultural symbol that represents any reality (e.g., in Russian culture, матрёшка, самовар).

Linguoculturological marking can be clearly manifested due to the inconsistency of the concept represented by a particular lexical unit with its equivalent in another language. For example, in the Russian administration, the words president and prime minister, and in Germany the words president and chancellor, do not conceptually represent the same concepts; the German-speaking president is not equivalent to the Russian-speaking president. A.N. Belyaev conditionally considers the words of the president and chancellor to be equivalent. Based on the opinion of the scientist E.V. Paducheva, he concludes that "there are concepts that exist in one worldview, but may not exist in the other." According to experts, linguocultural linguistic expressions have the ability to create "culturally conditioned images."

Traditionally thematic annotation plays an important role in language corpus meta-metrics. For example, the semantic tags of the descriptive linguistic corpus of the Grodno regional media are political and public life (1); health and medicine (2); agriculture (3); education (4); arts and culture (5); recreation, attractions and recreational facilities (6); sport (7); business (8), commerce, economics, finance and privacy (9); administration and management (10); events (11); crime (12); religion (13); law (14); defined as nature (15).

The genre core of the corpus is the text types note; information; article; reportage; interview; chronicle; advertising; congratulations; comment; user reviews; report; announcement; advice; represented by LSGs such as essays.

The language of the media in the Grodno region, highlighted by researchers in the field of "media linguistics", confirms the diversity of fundamental functional styles in the texts of the media, which are becoming increasingly the object of study. The materials presented in the numerous texts of various media outlets of the Grodno region are typical of the journalistic style: accordingly, the corpus 
contains material in the field of art (including poetry), official-administrative, scientific-popular, religious-church, domestic service. It deserves special attention in the field of advertising and electronic communications. The meta-marking parameters described above do not, of course, represent all types of linguistic material presented in the media corpus of the Grodno region. Nevertheless, they are enough to give an idea of the thematic, stylistic and genre diversity of this corpus. This defines the directions in which it can be used for large-scale research and didactic purposes.

The main feature of the media corpus of the Grodno region is a mixed character, which allows the linguistic corpus to be perceived as a completely different corpus. This feature of the corpus is closely related to the equal use of two languages in Belarusian society. Thus, the presence of Russian and Belarusian discourses, which are manifested at different levels in the corpus, gives the corpus originality.

The text of the articles may contain additional text in a language other than the main text language.

Here it is common for Russian material to intersect with Belarusian, and for Russian-language material to be dominated by Russian elements (Polish, English, and other linguistic elements are rare). This ensures the active emergence of expressions of the Belarusian language and culture in the corpus. The following factors can be mentioned as reasons for the conscious use of Russian and Belarusian language materials in the Grodno media corpus:

a) be an official periodical that defines the indicator in the name of the republic, region, district, city events, festivals, holidays, etc .;

(such names are given in one of the state languages of the Republic of Belarus: Belarusian / Russian; they appear in announcements, newsletters;

b) reference to the current official document, literary source, archival sources (mainly Russianlanguage sources of the Russian Federation, the USSR), language materials indicate that the author does not translate the quotation in this case;

c) the practice of self-quoting, which is typical for periodicals (by linking to a previously published article title, excerpts, title) with the "mixed" nature of the publication, ie if there is an article in Russian and Belarusian;

d) selection of the type of text by the reporter / journalist to establish the dialogue (conducted in a multi-ethnic region).

Examples of such text are:

1) group interview (roundtable, hotline, etc.);

2) questionnaire ("correspondence interview", if more than one respondent answers a certain question (s), the language of the answer may not correspond to the language of the question);

3 ) the text of the structure "the text of the correspondent who introduces and interprets to the reader the microtext created on one subject (for example, the photo)".

The main part of the acquisitions in the corpus is associated with famous noun. The Russian word in Belarusian usually includes the following thematic groups:

1) event (action; competition, including ceremonial performances, holidays, festivals, fairs, exhibitions; concerts; performances);

2) name of the organization (publishing house, museum, gallery; sports, tourist and agricultural complexes; camp; enterprise, firm and shops);

3) names of associations (club; creative association, ensemble, choir and vocal groups; theater; sports associations);

4) the name of the newspaper and magazine and their part: article, cycle, newspaper headlines;

5) name of the award (names of badges, orders and medals; festival nominations).

Relatively rare cases of acquisition include the following groups:

1) the name of the objects of worship (the name of the icon);

2) the name of the book, booklet (including the names of the series books); 
3) names of songs, musical, musical-choreographic compositions;

4) product name;

5) the name of the serial product;

6) nicknames;

7) names of heroes;

8) toponyms;

9) hydronyms.

\section{V.Conclusion}

Based on the above opinion of L.V. Rychkova, A.Y. Stankevich, it can be concluded that the linguistic corpus of Grodno media materials is a multi-purpose electronic resource: it allows conducting research in various linguistic, cultural, in particular, interlingual, intercultural relations.

Firstly, the corpus can objectively reflect the sociocultural expressions of the Belarusian dialect of the Russian language; serves as an effective tool for reflecting the long-term unbalanced multilingual existence of the ecolinguistic situation in the Russian-speaking region of the multi-ethnic non-Russian region.

These include the task of identifying differences in the axiological picture of the inner world of native-speaking, close but not identical cultures. This linguistic corpus is also important in didactics: the more the corpus provides information about the theory of language, the more microtext can be used from the sociolinguistic point of view, because it reflects the real practice, which is important in teaching Russian. In particular, it plays an extremely important role in teaching Russian as a foreign language. The electronic nature of the available language resource, its availability on the Internet, serves as an important tool in providing the learner with independent work, including distance learning mode.

\section{References:}

1. Maslova V.A. Linguoculturology. - M .: "Academy", 2001. - pp. 60-62

2. Golovko J.S. Culture and language: aspects of interaction // Scientific Bulletin of BelSU. - No. 12 (52) 2008. pp. 173-179.

3. Alefirenko N.F. Modern problems of the science of language. - M .: Flinta: Nauka, 2005 - P. 271.

4. Galimova E. Our most extraordinary language is still a mystery ... // Russian people, Russian culture and Russian language.M .: IIPK "Ichthyos", 2007. - P.71.

5. A. N. On the relationship between language and culture // Philological sciences. Questions of theory and practice. - Tambov: Diploma, 2016. No. 10 (64): in 3 hours, Part 2. P. 75-79. (Maқola manzili: www.gramota.net/materials/2/2016/10-2/22.html)

6. Humboldt V. von. Selected works in linguistics / per. with him. ed., with a foreword. G.V. Ramishvili. Moscow: Progress, 1984. - Pp.127-128, 397

7. Alefirenko N.F. Poetic energy of the word: synergetics of language, consciousness and culture. M .: Academia, 2002 .-- $391 \mathrm{p}$.

8. Vorobyov V.V. Cultural linguistics: theory and methods. M .: Publishing house of RUDN, 1997. - $331 \mathrm{p}$.

9. Gazizov R.A., Muryasov R.Z. Linguoculturology and modern lexicography // Bulletin of the Bashkir University. 2016. T. 21. No. 2. - Pp.413-421.

10. Esin A.B. Introduction to cultural studies: the basic concepts of cultural studies in a systematic presentation..: Publishing house. Center "Academy", 1999. - 216 p.

11. Ivanova S.V. Linguoculturological aspect of the study of linguistic units: author. diss. doct. philol. n. - Ufa, 2003.41p . 
12. Ivanova S.V., Chanysheva Z.Z. Linguoculturology: problems, searches, solutions: monograph. Ufa: RITs BashGU, 2010.366 p.

13. Kobozeva I.M. Linguistic semantics. M .: Editorial URSS, 2000 .-- 352 p.

14. Krasnykh V.V. Ethnopsycholinguistics and cultural linguistics: a course of lectures. M .: ITDGK "Gnosis", 2002. $-284 \mathrm{p}$.

15. Kubryakova E.S. In Search of the Essence of Language: Cognitive Research. Moscow: Znak, 2012 .-- 203p.

16. Popova T.G. National-cultural semantics of language and cognitive-socio-communicative aspects (based on the material of English, German and Russian languages): monograph. M .: Publishing house of MGOU "Nar. teacher ", 2003. 145 p.

17. Shaklein V.M. Linguoculturology: traditions and innovations: monograph. M .: Flinta, 2012 .-- 301 p.

18. Gazizov R.A., Muryasov R.Z. Linguoculturology and modern lexicography // Bulletin of the Bashkir University. 2016.Vol. 21.No. 2. - Pp.413-421.

19. Krasnykh V.V. Ethnopsycholinguistics and linguoculturology: a course of lectures. M .: ITDGK "Gnosis", 2002. 284 p. - P. 13.

20. Belyaev A.N. On the relationship between language and culture // Philological sciences. Questions of theory and practice. - Tambov: Diploma, 2016. No. 10 (64): in 3 hours - Part 2. - pp.75-79. (Maқola manzili: www.gramota.net/materials/2/2016/10-2/22.html)

21. Rychkova L.V., Stankevich A.Y. Multipurpose linguistic corpus of regional media // Information and communication technologies in linguistics, linguodidactics and intercultural communication. Issue 6: Sat. Art. / Ministry of Education and Science of the Russian Federation [and others]; ed.

22. A.L. Nazarenko. - M .: Center Distanz. Education: Faculty of Foreign lang. and regional studies MSU named after 23. M. V. Lomonosov; Publishing house "University book", 2014. - pp. 488-499. 